\title{
THE IMPLEMENTATION OF FUN FISHING TO TEACH SPEAKING FOR ELEMENTARY SCHOOL STUDENTS
}

\author{
Robekka Risten Fransiska Sinaga ${ }^{1}$, Lulud Oktaviani ${ }^{2}$ \\ Universitas Teknokrat Indonesia ${ }^{1,2}$
}

ristenrebecca@gmail.com¹, lulud_oktaviani@teknokrat.ac.id²

\begin{abstract}
Received: 8 May 2020
Accepted: 10 June 2020

Abstract

To produce competitive students that ready to face the trend of language learning in English as a foreign language, especially speaking skills, teachers should be ready to develop good planning in the teaching process. It can be in the form of strategies that can motivate students in the learning process. Moreover, in teaching elementary school students, teachers should be more creative to encourage students' motivation in speaking by using attractive teaching media which involves physical activity because young learners usually only have a short attention span. By using teaching media, students will learn a language in such attractive and fun ways. Thus, the researchers want to see the use of Fun Fishing in teaching speaking at one of the Elementary Schools in Lampung to encourage students in learning English. This research used a qualitative method since it disclosed how to implement Fun Fishing media in an Elementary School in Lampung. As a result, the students were divided into four groups consisted of 2-3 members and learned English which involved physical activity. To sum up, using this media in learning English can motivate students to speak in English and make teaching and learning become more fun because they did physical activity.
\end{abstract}

Published: 27 June 2020

Keywords: teaching media, elementary school, teaching English

\section{To cite this article:}

Sinaga, R. R. F. \& Oktaviani, L. (2020). The Implementation of Fun Fishing to Teach Speaking for Elementary School Students. Journal of English Language Teaching and Learning, 1(1), 1-6.

\section{INTRODUCTION}

Communication is simply the act of transferring information from one place, person or group to another. Every communication involves the sender and recipient that sharing information, through communication, people can interact with each other because they can express what is in their mind. It is in line with Sari (2018) who assert that interaction plays pivotal roles and appears when the communication among teacher and students occurs by sharing the information and knowledge in the classroom activities.

According to the national standards in Indonesia (Depdiknas, 2006), oral communication competence or listening and speaking skill is the goal of English learning in elementary schools. As a global language English plays an important role in the world. People from many different countries who share many different languages can communicate with each other by using English, this condition makes English important to be mastered (Kayi, 2006). Moreover, Nunan (2013) also said that "Speaking is one of the important and essential skills that must practice communicating orally, and it is a priority for many second and foreign language learners." By seeing that importance, teachers have to find a way in teaching oral communication and pay attention to some factors such as tasks given (Kuswoyo and Wahyudin, 2017) and characteristics and learning styles (Wahyudin and Rido, 2020) of their students. It is in line with Oktaviani (2016) that the speaking skills of EFL students influenced by some factors.

Besides factors, students also have their characteristics in learning, especially elementary schools' students who are considered as young learners. Young learners usually take great pleasure in having fun in what they do. So, elementary school teachers should understand their world. Moreover, they also should have the ability to teach them communicatively and effectively based on appropriate teaching media. Using teaching media in teaching gives some benefits that can cope with the students' characteristics (Wahyudin, 2020). Oktaviani and Mandasari (2020) stated that using media in teaching can improve students' motivation in learning English. 
Therefore, teaching English to elementary schools' students must be well designed following the characteristics of the students because teaching English as a foreign language is not as easy to be done. Several studies have found that learning English at earlier ages is effective and very helpful in developing children's English proficiency (Shin, 2010; Gawi, 2012). The biggest challenge is how to make the students speak English during the learning process because the student mostly used their mother tongue as their communication tool and the lack of vocabulary as one of cause why the students do not want to speak English during the English class. Beside that Kayi (2006) stated that teacher should provide speaking activities which focus more on meaningful communication than leading the students to pure memorization. It is in line with Wallace et al. (2004) that teachers have to provide students with opportunities for practicing speaking English. This practice speaking can lead to meaningful communication than only memorizing (Wahyudin, 2017).

Elementary school students are still at an early age which is about 8 to 12 years old with more complicated characteristics compared to older students. Personalities of students also become more noticeable and difficult to handle. So, as a teacher do not push them if they are reluctant to follow the tasks of the teacher but choose the right teaching strategy. Be careful not to let an activity go on too long - they are still children. They often enjoy doing an activity. It implies that teaching English such age should be well managed. Where in the process of teaching and learning in the classroom the students tend to be very active playing with their friends and it is hard to ask the students to be seriously joining the English class. The teacher should try hard to encourage the students to reach the purpose of English learning, especially in speaking. Based on the characteristics above, the researchers come up with "How to implement Fun Fishing to teach English in Elementary School in Lampung?".

Fun Fishing is a teaching media that modified from a small snake and ladder board to become very big board sharks and fish rods. Since it is very big, the students can play above the board as a player. The dice also become big. So, before the students stand above the board they have to throw the dice and speak based on the instructions provided by the teacher. If they speak based on teacher instructions correctly, they can jump and move to the next number. However, if they speak incorrectly, they need to jump backward based on the number of dice they throw. Besides, if they get to fish hook, they can go up to the number where the fish rod takes a place. Unluckily, if they get to the mouth of the shark, they need to go down to the tail of the shark.

\section{METHOD}

The researchers used qualitative research because the researchers wanted to describe how the students learned English used Fun Fishing Media to improve their speaking skills in elementary school. Fraenkel and Wallen (2012) define that a qualitative is a study that investigates the quality of relationships, activities, situations, or material. This research took place in one of the Elementary Schools in Lampung. The students formed fifth grade.

The implementation of Fun Fishing in the fifth grade of elementary school because of the characteristics of young learners is very active and takes great pleasure in having fun in what they do, especially physical activity. In their age, they often enjoy and actively playing with their friends. The researchers tried to combine teaching and playing together. This subject focused on the introduction which covered hometown, name, and members of a family, introducing their friends or favorite places. So, the students need to play, think creatively, and also speak confidently in English class.

\section{FINDINGS AND DISCUSSION}

The application of fun fishing is to motivate the students' skills to learn English with a fun atmosphere and to train the students to work together to reach to be a winner (Feng et al., 2013). In implementing fun fishing in a class, the researchers involved pre-teaching, whilst teaching, and post-teaching activities. The details are as follows:

\section{- Pre-teaching}

1. Greeted the students.

2. Asked the students' condition.

3. Checked the students' attendance.

4. Asked the students' previous material.

5. Brainstormed the students' by asking what game they played recently.

\section{- Whilst Teaching}

1. Explained the material "Family Members"

2. Gave the students some pictures related to the material.

3. Asked the students to repeat the pronunciation several times.

4. Checked the students' pronunciation. 
5. Showed some questions/instructions to ask about "Family members"

6. Showed some possible answers regarding the questions.

7. Checked the students' understanding by having a question and answer session.

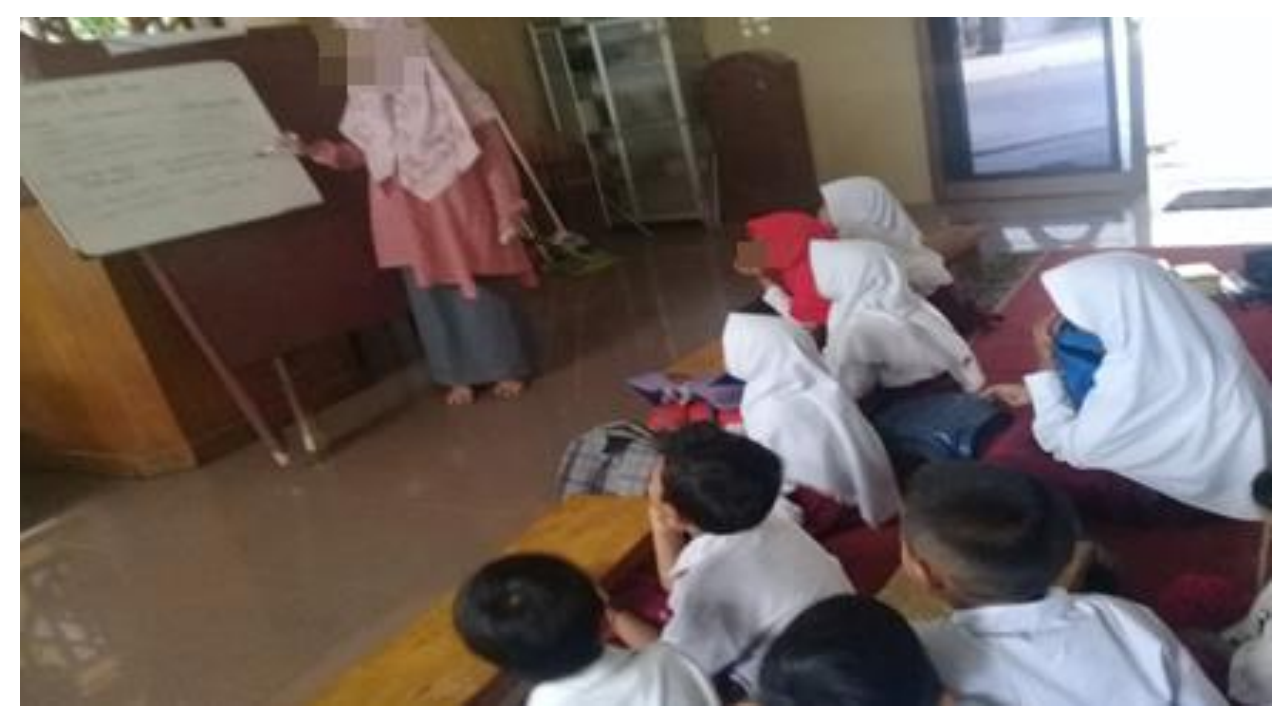

Figure 1. The teacher asked some questions to check students' understanding

\section{- Post-teaching}

Fun Fishing game was implemented in post-teaching because of the purpose of this game to enhance students' understanding of the material given by the teacher. It is in line with Sukarno (2012) that "...in a post-method a teacher can adapt, adopt, select, develop, create suitable teaching material...”. The following are the steps in post-teaching:

1. Explained the rule of playing fun fishing:

- The students of every group will take turns to throw a dice.

- The student or first player of every group throws the dice and speaks based on the instructions provided by the teacher. If he/she speaks based on teacher instructions/questions correctly, they can stand above the number they get on a Fun Fishing board. This activity will be repeated until all the first players of the group do it.

- After that, the first student of the first group will throw the dice for the second time and repeat the activity for the next player of other groups.

- If the students speak correctly, they can jump and move to the next number. However, if they speak incorrectly, they need to jump backward based on the number of dice they throw.

- The students will get benefits if they get to fish hook because they can go up to the number where the fish rod takes a place. Unluckily, if they get to the mouth of the shark, they need to go down to the tail of the shark.

- After the first player finishes playing, the one who throws the dice will be a second player of his/her group. This activity will continue until all the members of the group play and one group finish playing with all the members.

2. Divided the students into four groups and each group consists of 3-4 members.

3. Asked the students to take turns to throw the dice and speak.

4. The fastest group to reach the final number was the winner.

5. Gave the students advice about the winner and loser in a game.

6. Congratulated the winner group and gave support to the looser groups.

7. Asked the students whether they have questions or not.

8. Closed and conclude the material of the day.

9. Greeted the students. 


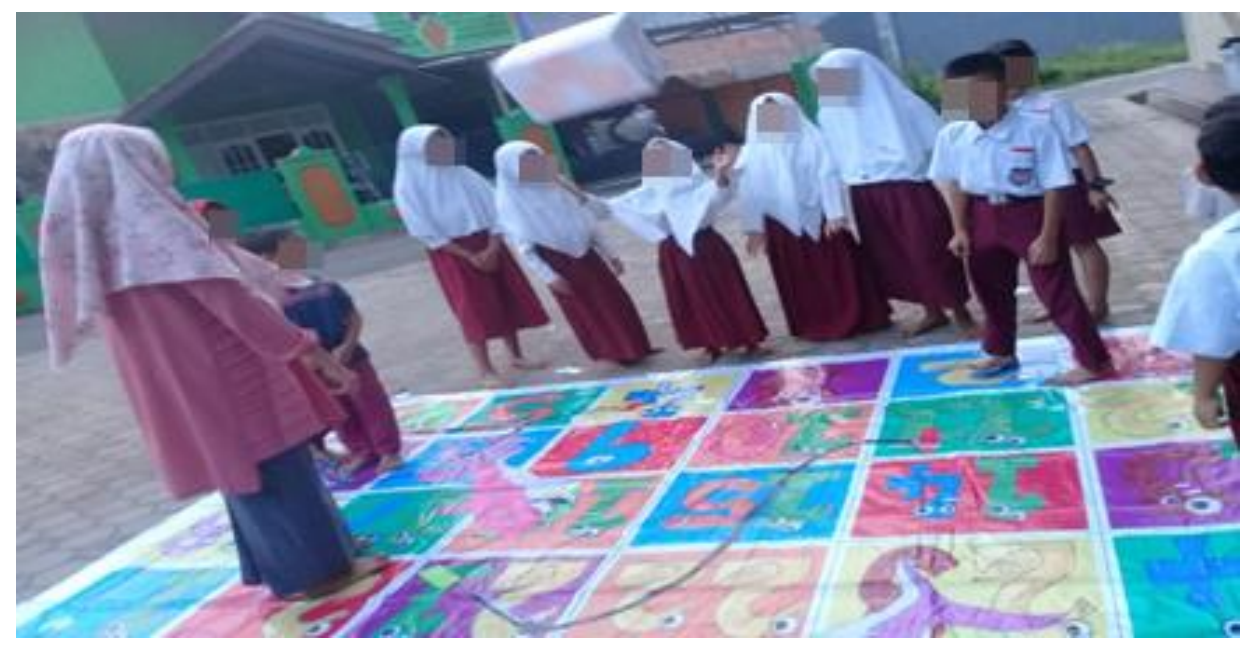

Figure 2. Implementation of Fun Fishing

Table 1. List of topic questions

\begin{tabular}{cl}
\hline No. & Topic's questions \\
\hline 1. & Introduction \\
2. & Favorite foods and drinks \\
3. & Family members \\
4. & Describing place \\
5. & Favorite things to do \\
\hline
\end{tabular}

The list of topic questions in the table above was the topic provided by the teacher but future teachers or researchers can change or improve based on the topic discusses in their syllabus. Abdulhak (2013) said that material or topics in a game can be changed or improved depends on the teacher's syllabus. This fun fishing game can be modified by the teachers by changing the instruction/questions based on the material on the syllabus itself. So, the teachers only need to create the dice and print the board once but create as many as possible questions/instructions. Thus, the teacher can often have fun activities but do not spend much time in preparing the teaching media itself just like Sukmahidayanti (2015) said that elementary school teachers used to implement teaching media in teaching because it is expensive, needs much time to prepare, and requires teachers to join some training programs.

By using a Fun Fishing in a class, the students will try to think and discuss with their friends to speak in English. For example, the first group who rolled the dice will get the instruction, like "tell your favorite place." and answered, "My favorite place is Lembah Hijau." This activity runs smoothly because they speak while playing and had more motivation because they wanted to finish the activity as soon as possible. Moreover, the students did not sit on their chairs, so they seemed to enjoy the activity and were in an informal situation. Some of the students who supported their friends even jumped around the board because they got excited whenever their friends got the correct answer. Zirawaga et al. (2017) said that a game in education has many benefits, some of them that it can motivate students in learning and improve their interaction with their friends. Thus, although preparing a game needs more time and energy, it can give some benefits to both teachers and students in the teaching and learning process in a class.

A game in the teaching and learning process is not only for those who are still in kindergarten, elementary, junior, or even elementary school but also it helps those who are in higher education or university level. Oktaviani and Desiarti (2017) implemented a game called Ethnic Snake Game for university freshmen students at Universitas Muhammadiyah Malang. As a result, both lecturers and students thought that using a game, multimedia, in a class could make both of them enjoy the teaching and learning process in a class. Moreover, this multimedia game could also become a trigger for students to learn and improve their activity. Besides a game implemented in the class, there is also an alternative for teachers to make the class interesting by using a learning application since it is also a trigger for students to learn in a very attractive way and boost their English skills without having a monotonous activity in a class (Wahyudin et al., 2020). It is in line with Aminatun and Oktaviani (2019) that applying language learning applications in an English class can build the students learning autonomous skills and interestingly support their independence learning. 


\section{CONCLUSION}

It is very clear from the findings and discussions that students can improve their speaking skills by using Fun Fishing, multimedia, and clear instructions which has colorful media, interesting questions. This is easily adopted to be one of the attractive ways to show the process of improving the students in the class. Moreover, matching with elementary student's characteristics who are comfortable with colorful media and movement activity, the students showed a positive response to the use of Fun Fishing. Thus, this media can be adopted by other teachers to teach in the classroom.

\section{REFERENCES}

Abdulhak, I. \& Damawan, D. (2013). Teknologi Pendidikan. Bandung: Rosdakarya.

Aminatun, D. \& Oktaviani, L. (2019). Memrise: Promoting Students' Autonomous Learning Skills through Language Learning Application. Metathesis: Journal of English Language, Literature, and Teaching, 3(2), 214-224. DOI: $10.31002 /$ metathesis.v3i2.1982.

Brumfit, Moon, C. J., \& Tongue, R. (1995). Teaching English to Children. New York: Longman Group Ltd.

Depdiknas. (2006). Kurikulum Tingkat Satuan Pendidikan (KTSP). Jakarta: Departemen Pendidikan Nasional.

Feng, H. Y., Fan, J. J., \& Yang, H. Z. (2013). The Relation of Learning Motivation And Achievement in EFL: Gender as An Intermediated Variable. Educational Research International, 2(2), 50-58. http://www.erint.savap.org.pk/PDF/Vol.2(2)/ERInt.2013(2.2-07).pdf.

Gawi, E. M. K. (2012). The Effects of Age Factor on Learning English: A Case Study of Learning English in Saudi Schools, Saudi Arabia. English Language Teaching, 5(1), 127-139. URL: http://dx.doi.org/10.5539/elt.v5n1p127.

Kuswoyo, H. and Wahyudin, A. Y. (2017). Improving Student's Listening Skill Using Task-Based Approach in EFL Classroom Setting. Paper presented on 4th Asia Pacific Education Conference (AECON 2017). Retrieved at https://www.atlantis-press.com/proceedings/aecon-17/25884229

Kayi, H. (2006). Teaching speaking: Activities to promote speaking in a second language. The Internet TESL Journal, XII(11). Retrieved from http://iteslj.org/

Nunan, D. (2003). Practical English Language Teaching. Boston: McGraw Hill.

Oktaviani, L. (2016). Studi Tentang Faktor yang Mempengaruhi Kemampuan Berbicara Jurusan Bahasa Inggris di Universitas Muhammadiyah Malang. In Tursini, U. et al. (Eds.), Seminar Nasional: Paper was presented in Membangun Karakter Dosen sebagai Peneliti dan Pengabdi dalam Memasuki Persaingan Global: Prosiding Seminar Nasional Hasil Penelitian (pp. 342-246). Malang: LPPM Universitas Kanjuruhan Malang.

Oktaviani, L. \& Desiarti, E. (2017). A Lecturer's and Students' Perspective toward Ethnic Snake Game in Speaking Class at Universitas Muhammadiyah Malang. Teknosastik: Jurnal Bahasa dan Sastra, 15(2), 53-59. DOI: https://doi.org/10.33365/ts.v15i2.98

Oktaviani, L. \& Mandasari, B. (2020). Powtoon: A Digital Medium to Optimize Students' Cultural Presentation in ELT Classroom. Teknosastik: Jurnal Bahasa dan Sastra, 18(1), 33-41. DOI: https://doi.org/10.33365/ts.v18i1.526.

Sari, F. M. (2018). Patterns of teaching-Learning Interaction in the EFL Classroom. Teknosastik: Jurnal Bahasa dan Sastra, 16(2), 41-48. DOI : 10.33365/ts.v16i2.139.

Shin, S. J. (2010). Teaching English language learners: Recommendations for early childhood educators. Dimensions of Early Childhood, 38(2), 13-21.

Sukarno. (2012). Applying Post-Method in Teaching English to Young Learners. Presented on The $2^{\text {nd }}$ National Conference on Teaching English for Young Learners in Indonesia: from Policy to Classroom. Syafe' I, M., Madjdi, H., \& Mutohhar (Eds), Universitas Muria Kudus, $\quad$ Kudus, Indonesia, 232-243. https://eprints.umk.ac.id/340/29/PROCEEDING_TEYLIN_2.238-249.pdf.

Sukmahidayanti, T. (2015). The Utilization of Instructional Media in Teaching English to Young Learners (A Case Study of an Elementary School Teacher in Bandung). Journal of English and Education, 3(2), 90-100. https://media.neliti.com/media/publications/191806-EN-the-utilization-of-instructional-media-i.pdf

Wallace, T., Stariha, W. E., \& Walberg, H. J. (2004) Teaching, Speaking, Listening and Writing. Geneva, Switzerland: UNESCO.

Wahyudin, A. Y. (2017). The Effect of Project-Based Learning on L2 Spoken Performance of Undergraduate Students in English for Business Class. Paper presented on The Ninth International Conference on Applied Linguistics (Conaplin 9), 42-46. Retrieved at https://www.atlantis-press.com/proceedings/conaplin-16/25874124

Wahyudin, A. Y. \& Rido. A. (2020). Perceptuals learning styles preferences of international master's students in Malaysia. BAHTERA : Jurnal Pendidikan Bahasa Dan Sastra, 19(1), 95-103. https://doi.org/10.21009/bahtera.191.10.

Wahyudin, A. Y., Jepri, D., Simamora, M. W., Pratiwi, I. W., \& Rina, A. (2020). Penggunaan komik digital Toondoo dalam pembelajaran Bahasa Inggris tingkat sekolah menengah. Journal of Social Sciences and Technology for Community Service (JSSTCS) 1(1), 1-6

Zirawaga, V. S., Olusanya, A. I. \& Maduku, T. (2017). Gaming in Education: Using Game as a Support Tool to Teach History. Journal of Education and Practice, 8(15), 55-64. https://files.eric.ed.gov/fulltext/EJ1143830.pdf 


\section{BIOGRAPHY OF AUTHORS}

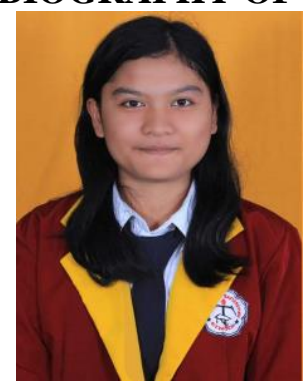

Robekka Risten Fransiska Sinaga is a student at English Education study program in Universitas Teknokrat Indonesia. During her study, she has achieved some regional and national achievements, such as top ten national teaching media competition in Pekan Pendidikan Generasi Hebat 2018 in Universitas Muhammadiyah Makasar, the best student of English Education 2019, and the winner in Lomba Inovasi Digital Mahasiswa 2019 in Universitas Negeri Jogjakarta. She also obtained a Copyright from the Ministry of Law and Human Rights in 2018 for Fun Fishing Game.

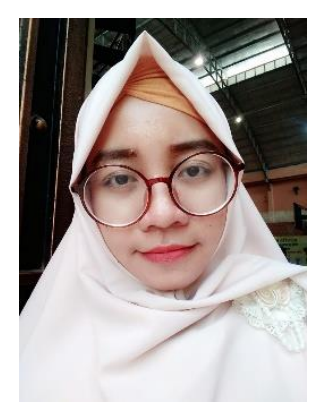

Lulud Oktaviani is an English Education Lecturer in Universitas Teknokrat Indonesia. Besides teaching, she actively presents her paper at national and international conferences and publishing her research in proceedings and journals. Her research interest is teaching media, English teaching, and learning, English as a second language. She also has obtained fundings from the Directorate of Research and Community Service in Higher Education five times for Penelitian Dosen Pemula (PDP) and Program Kemitraan Masyarakat (PKM). 